Article

\title{
Analysis of Fuel Cell Driven Ground Source Heat Pump Systems in Community Buildings
}

\author{
Jae-Ki Byun ${ }^{1}$, Dong-Hwa Jeong ${ }^{2}$, Young-Don Choi ${ }^{1, *}$ and Jong-Keun Shin ${ }^{3}$ \\ 1 Department of Mechanical Engineering, Korea University, Anam-dong, Seongbuk-gu, \\ Seoul 136-713, Korea; E-Mail: bjky21@korea.ac.kr \\ 2 NSSS Division, KEPCO Engineering \& Construction Company Inc., 1045 Daedeok-daero, \\ Yuseong-gu, Daejeon 305-353, Korea; E-Mail: dhjeong@kepco-enc.com \\ 3 Department of Automotive Engineering, Hanzhong University, San 119, Jiheung-dong, Donghae, \\ Gangwon-do 240-713, Korea; E-Mail: jkshin@hanzhong.ac.kr \\ * Author to whom correspondence should be addressed; E-Mail: ydchoi@korea.ac.kr; \\ Tel.: +82-2-3290-3355; Fax: +82-2-928-1607.
}

Received: 3 April 2013; in revised form: 28 April 2013 / Accepted: 29 April 2013 /

Published: 7 May 2013

\begin{abstract}
In the present study, a fuel cell driven ground source heat pump (GSHP) system is applied in a community building and heat pump system performance is analyzed by computational methods. Conduction heat transfer between the brine pipe and ground is analyzed by TEACH code in order to predict the performance of the heat pump system. The predicted coefficient of performance (COP) of the heat pump system and the energy cost were compared with the variation of the location of the objective building, the water saturation rate of the soil, and the driven powers of the heat pump system. Compared to the late-night electricity driven system, a significant reduction of energy cost can be accomplished by employing the fuel cell driven heat pump system. This is due to the low cost of electricity production of the fuel cell system and to the application of the recovered waste heat generated during the electricity production process to the heating of the community building.
\end{abstract}

Keywords: ground source heat pump (GSHP); community building; fuel cell 


\section{Introduction}

The development of renewable energy is becoming an urgent issue as global warming is accelerated due to resource depletion and environmental pollution. Geothermal energy, which is one of the renewable energy sources recently receiving attention, can be used to run an energy saving cooling and heating system. The system is called the geothermal energy heat pump system. The geothermal heat pump system has high capability of utilization in both the summer and winter. Its annual cost of maintenance is low compared to present cooling and heating apparatus. It is also environmentally friendly as it emits less household gases such as $\mathrm{CO}_{2}$. However, despite these benefits, various limits are involved in the ground heat exchanger installation site and the initial installation cost.

On the other hand, the air source heat pump, which can perform heating and cooling alternatively with a simple directional diverter valve, is acknowledged as a typical energy saving device and is widely used in leading countries. Ground heat, which is used as the heat source for the heat pump, is superior to other heat sources in its ease of applicability and lower maintenance cost. However, the weakness of the air source heat pump is that the heat pump performance is greatly influenced by the outdoor air temperature condition [1].

Thus, in order to supplement the weaknesses of the ground source and air source heat pumps and to improve system performance, a hybrid ground source heat pump was developed. The ground heat exchanger and a hybrid heat pump with an assistant heat source are widely used in America and Europe. Generally, a hybrid ground source heat pump is a system that uses a ground heat exchanger along with an assistant heat source apparatus such as a cooling tower and boiler. The ground heat exchanger is utilized at a certain load, and the cooling tower is utilized simultaneously when the load is higher than that of the selected load. During heating, the boiler or solar panels used for general heating facilities are additionally installed in the geothermal heat pump and utilized as the assistant heat source. A system using a ground heat exchanger and an air source as the assistant heat source can also be considered as a hybrid geothermal heat pump system. These systems are developed to assist condenser heat radiation during cooling and evaporator heat absorption during heating, thus increasing system efficiency, resulting in a saving in electricity.

Previous studies include geothermal heat pump system design [2], heat pump system efficiency and economic feasibility analysis [3], hybrid geothermal system performance analysis [4] and design construction and construction criteria [5].

Healy et al. [3] analyzed a geothermal heat pump operation and performance characteristic through a numerical study of various parameters that effect geothermal heat pump performance. Stoecker [6] proposed a data processing model for a vapor compression system simulation analysis. The model is used to predict the total system performance based on the performance characteristics of each component (evaporator, condenser, compressor, and expansion devices).

Mei et al. [7] conducted a study on a high-efficiency ground coil heat exchanger, analyzing the water phase change and the ground temperature variation of the horizontal ground coil due to the seasonal change in the soil.

In America, research carried out on geothermal energy increased after the 1980s. In 1984, Bose [8,9] proposed that for a vertical ground heat exchanger it is valid to use an equivalent diameter and to consider the two tubes in the U-tube as one tube while deriving heat characteristics. Later, in 
1988, Bose was also the first to describe soil temperature variation around a vertical heat exchanger using an analytical method. Kavanaugh [10] constructed a test module for measuring pipe pressure loss and various heat losses in a geothermal heat pump system pipe design, thus describing the actual operation and yielding design values that can be utilized. It should be noted that Bose [8,9] and Kavanaugh [2] proposed the design criteria in the geothermal heat pump system, and provided the data of various examples of installed heat pump systems, thus accelerating the use of the geothermal heat pump [11].

Lund [12] showed a 58\% growth in geothermal heat pump system usage after 1995, and that the growth was 9.8\% annually, and around five million heat pump systems in use in America and European countries by the beginning of 2000s. Lund et al. [13] estimated the increase in the numbers of geothermal heat pump system being installed. Around 4.5 million geothermal heat pump systems were installed in America in 2005, with an increase of 0.5 million each year. The increase rates of installation were as follows: encapsulated type vertical heat exchanger, 46\%; encapsulated type horizontal heat exchanger, $38 \%$; open type system, $15 \%$; and overall installation, $10 \%$. In 2005 , the number of $12 \mathrm{~kW}$ capacity geothermal heat pump systems installed had doubled compared to that in 2000 and by 2010, about 15 million geothermal heat pump systems had been installed.

Zeng et al. [14] analyzed borehole heat transfer in a vertical ground heat exchanger while utilizing single U-tube and double U-tube units. Hepbasli et al. [15] conducted experimental research on geothermal heat pump performance with an encapsulated vertical ground heat exchanger. Bi et al. [16] analyzed the temperature distribution around a ground heat exchanger through theory and experiment. İnall et al. [17] analyzed seasonal ground temperature distribution and system performance while varying the burying depth of the ground heat exchanger in the horizontal geothermal heat pump system. Esen et al. [18] analyzed heat pump system performance of the horizontal geothermal heat pump system in cases where the heat exchanger burying depth was $1.0 \mathrm{~m}$ and $2.0 \mathrm{~m}$.

In this study, a fuel cell system was combined with a heat pump system and hybrid heat pump system currently in use. The fuel cell system transforms chemical energy directly to electrical energy, thus yielding higher efficiency compared to other electricity generating technologies. The cost is less than that of late-night electricity due to its capability to generate electricity on its own. Also, the waste heat from the fuel cell operation can be stored in the heat storage tank and used as a heat source, thus increasing the heat pump system coefficient of performance (COP) during heating.

\section{The Selection of Community Building for Numerical Analysis}

In this study, the object of numerical analysis is an actual building currently in operation. The specifications of the object community building are shown in Table 1 . This community building has lower load change compared to other buildings, and has a large annual load, which is economically beneficial. Thus the building was selected as the object for numerical analysis. Also, to increase the building area to $33,057 \mathrm{~m}^{2}$ and to observe the energy consumption variation according to regional change, the object building was fixed while the building location was varied, including Munmak, Daejeon, and Busan during numerical analysis. 
Table 1. Specifications of the object community building.

\begin{tabular}{cc}
\hline Item & Specifications \\
\hline Object community building & Oak Valley Resort \\
Location & Munmak, Gangwon-do, Korea \\
Area $\left(\mathrm{m}^{2}\right)$ & 27,028 \\
Number of persons & Maximum: 2,260 \\
\hline
\end{tabular}

\section{Numerical Analysis of Geothermal Heat Pump}

\subsection{Ground Source Heat Pump System}

A schematic of the fuel cell driven ground source heat pump system in this study, which is the object of the numerical analysis, is shown in Figure 1.

Figure 1. Schematic diagram of the fuel cell driven ground source heat pump heating and cooling system.

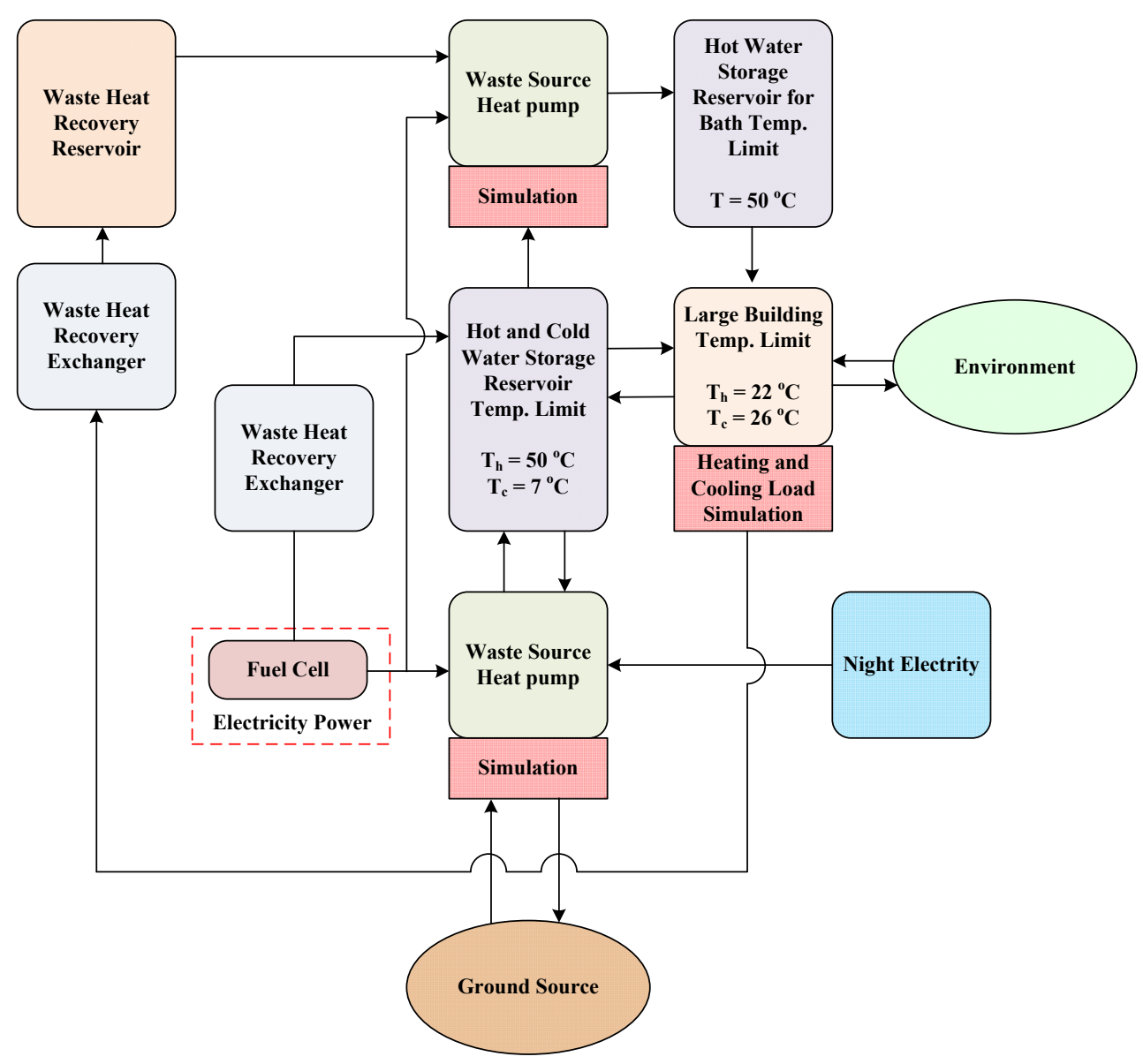

The heat pump system is a system combining a chilled water storage tank, a ground source heat pump, and a heat pump using bath water waste as a heat source. It consists of two heat pumps, while one heat pump can alternatively use the ground source and the waste heat as a source. In more detail, in the heat pump system, heat is stored in a chilled water storage tank with late-night electricity and heat from the fuel cell operation to be used during heating. Waste heat from the shower and bath water 
is stored in the hot water storage reservoir through the water source heat pump. Waste heat from the shower and bath water is stored in the hot water storage reservoir through the water source heat pump. In the case of cooling, the heat from the chilled water storage tank is pumped to the hot water storage reservoir using the water source heat pump so that both cold and hot heats are utilized simultaneously by a single heat pumping operation. This combined load system increases double the COP of the system. For numerical analysis of the heat pump system, the heating and cooling load calculation of the building, the heat pump capacity calculation, and the sub-program to predict ground temperature variation through the heat pump energy equilibrium equation are used to analyze two-dimensional heat transfer.

\subsection{Fuel Cell System Waste Heat Recovery Apparatus}

In a fuel cell system, waste heat recovery is more important than simply improving energy efficiency. According to the American DOE report [19], a polymer electrolyte membrane fuel cell system with $30 \%$ fuel-to-electricity efficiency can save up to $40 \%$ gas fuel when a waste heat recovery system with $65 \%$ efficiency is installed. In the actual fuel cell systems, water or air is used for cooling in order to maintain the optimal operation temperature, and pipelines are also already in the system. Thus, simple heat exchangers are added as shown in Figure 1 to store the heat generated during the fuel cell operation.

\subsection{Dynamic Analysis of Community Building Load}

In this study, the heat resistance-capacitance method [20,21] is used to calculate the heating and cooling load. In particular, the thermal-resistance capacitance method is widely used in the aviation industry. While a great deal of research has been carried out on the dynamic analysis of the building heating and cooling load such as DOE, BLAST, and TRNAYS [22-24], the program structure is complex and difficult to apply to building heating and cooling load calculation, and is also time-consuming. In this study, the entire building is considered in a one room equivalent model and a non-steady heat transfer equation is solved for the equivalent model to yield indoor temperature and wall temperature variation with time. Solar radiation load [25] due to solar radiation and permeability of solar radiation in the window are derived from the method proposed in ASHRAE Fundamentals [26]. Also, to obtain an infiltration air load, human body load, and other loads [27], numerical analysis was conducted while considering the object building's operation characteristics.

Lee et al. [28] applied thermal-resistance capacitance to office building energy consumption and the result showed the same accuracy as the dynamic analysis using the response factor method, with the error within 5\% compared to the TRACLOAD code [22]. Lee [21] and Choi et al. [23] found that heat performance concurred well with the results from the experiments by using the thermal-resistance capacitance method, and they conducted a simulation of the continuous heat supply control in a high-rise apartment building.

In this study, a program is developed to easily analyze a heat pump heating and cooling system through dynamic heat load analysis using the thermal-resistance capacitance method. 


\subsection{Analysis of GSHP Cycle}

In order to simulate the heat pump system, the cycles for the air source heat pump and water source heat pump must be simulated. In this study, the Engineering Equation Solver (EES) is used to simulate the heat pump cycle. Assumptions for the cycle simulation are as follows:

(1) Temperature difference between condenser and water is $\pm 5{ }^{\circ} \mathrm{C}$ in the heat pump heat storage tank or chilled cooling storage tank heat exchanger.

(2) Temperature difference between the outdoors and the evaporator or condenser is $\pm 10{ }^{\circ} \mathrm{C}$ for the evaporation and condensing in water-air heat exchange.

Procedures for simulating the heat pump with the EES code are as follows.

(1) Determine the evaporator temperature and condenser temperature and then calculate the R-22 refrigerant heat pump system coefficient of performance (COP) with the EES program.

(2) Ground brine temperature is altered automatically in response to the ground heat conduction condition until the total heat absorbed or emitted from the entire pipeline becomes $2 \mathrm{RT}$. 2RT is the postulated heating or cooling capacity of a module ground pipe hole.

\subsection{Ground Heat Exchange Analysis}

Figure 2 shows a schematic of a ground source heat pump system in a geothermal heat pump system with a vertical ground heat exchanger. The single U-tube vertical ground heat exchanger consists of two tubes with flowing fluid, grout, and a borehole which is the boundary of the soil and grout. In the case of the heat pump cooling operation, discharged fluid flows through the pipeline and passes through the tube and grout, emitting heat to the soil, and returns to the heat pump. In reverse, during the heating operation, the fluid discharged from the heat pump flows through the tube and absorbs heat from the soil and returns to the heat pump.

Figure 2. Schematic of a ground source heat pump system.

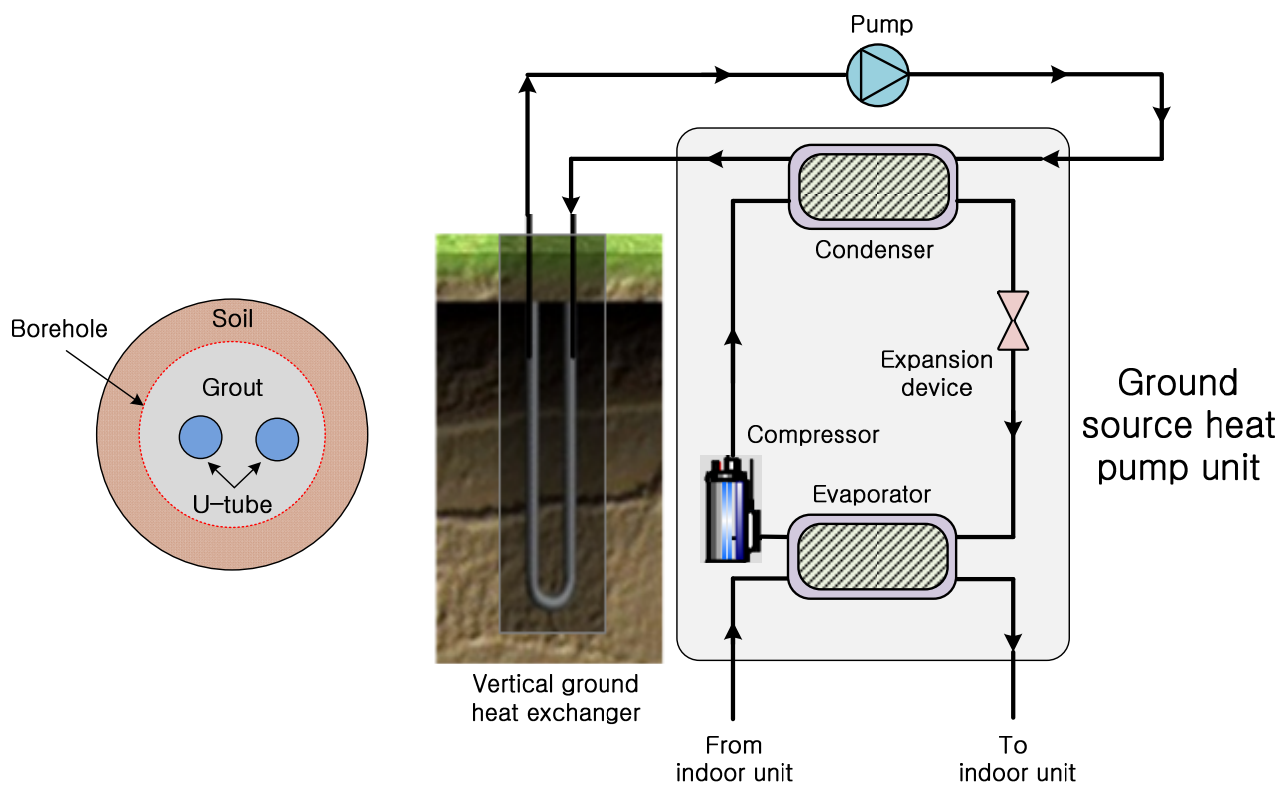


In this study, an equivalent tube is used to substitute the U-tubes, and the square calculation region is changed to a circular region, to simplify the simulation, as shown in Figure 3. Borehole pitch is assumed to be $4.5 \mathrm{~m}$ and borehole depth is $100 \mathrm{~m}$. The properties of the underground soil and bentonite, which fills the borehole, were selected as shown in Table 2. Equation (1) is used to calculate the valid thermal conductivity in the soil. Water contained in the underground soil was assumed to be $35 \%$ and $75 \%$ [24].

Figure 3. Transformation of a square domain to an equivalent concentric domain.

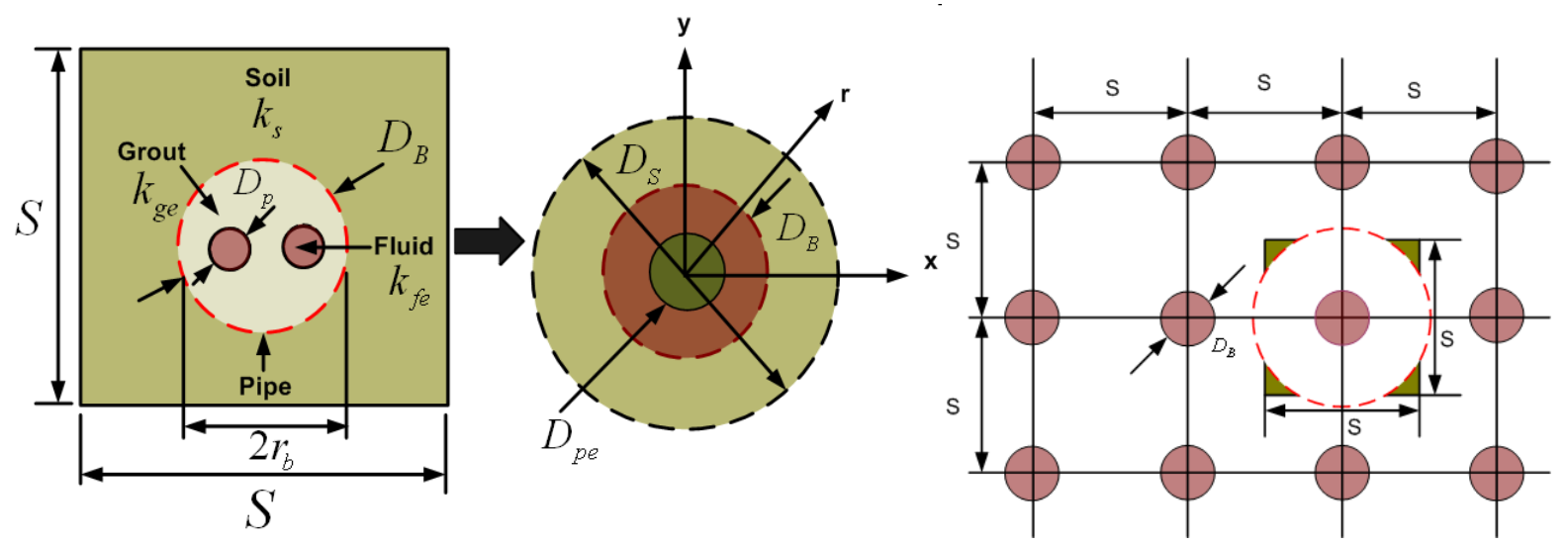

Table 2. Properties of the element of the ground heat exchanger.

\begin{tabular}{cccc}
\hline Material & Soil & Refrigerant (R-22) [27] & Grout (Bentonite) \\
\hline$\rho\left(\mathrm{kg} / \mathrm{m}^{3}\right)$ & 2600 & 1133 & 1800 \\
$C_{p}(\mathrm{~J} /(\mathrm{kg} \mathrm{K}))$ & 837 & 1332 & 500 \\
$k(\mathrm{~W} /(\mathrm{m} \mathrm{K}))$ & 3.1 & 0.077 & 2.66 \\
\hline
\end{tabular}

The valid thermal conductivity of the soil is:

$$
\frac{1}{k_{g}}=\frac{1-\Phi}{k_{s}}+F \cdot \frac{\Phi}{\left(1-S_{a}\right) k_{a}+S_{a} k_{w}}
$$

where $F=0.5(\varepsilon+0.014)^{0.25} ; \varepsilon=S_{a} \cdot \Phi$. Here $k_{s}, k_{a}, k_{w}$ represent the thermal conductivity of soil particle, air, and water, respectively. $\Phi$ is underground soil porosity and $S_{a}$ is the degree of saturation. The single module for the ground heat exchanger is a square with the length of each side $S$ as shown in Figure 3. $D_{B}$ is the grout diameter and $D_{p}$ is the ground pipe diameter. The square region is substituted for the circular region with equivalent diameter $D_{s}$, while the two circular tubes with diameter $D_{p}$ are substituted for the equivalent tube with diameter $D_{p c}$. The equivalent diameter $D_{p \mathrm{c}}$ is calculated as $\sqrt{2} D_{p}$, while the ground equivalent diameter $D_{s}$ is $\sqrt{2} S$.

Figure 4 shows the mesh generated to analyze ground temperature distribution. Fine mesh is used for regions where rapid temperature variation due to heat pump system operation is expected to occur. The TEACH code program was used for the ground heat transfer method [27] during simulation. A pipe depth of $100 \mathrm{~m}$ and a ground depth $150 \mathrm{~m}$ were analyzed, while the borehole pitch $S$ varied. 
Figure 4. Transformation of a square domain to an equivalent concentric domain.

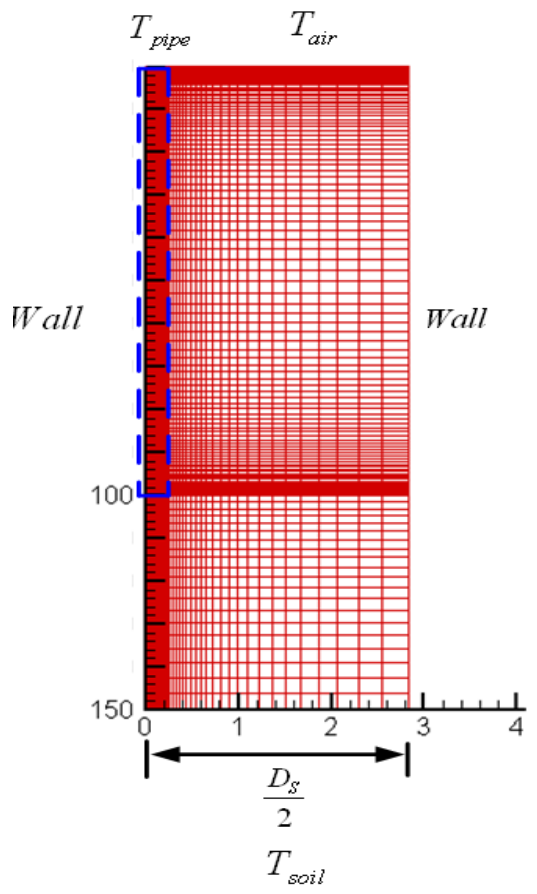

\subsection{Governing Equation and Boundary Condition}

The U-tubes are substituted for an equivalent tube as shown in Figure 3, and an assumption is made that the heat velocity originated from the equivalent tube and was transferred to the ground through the grout. The heat velocity has a positive value when the heat is transferred from a refrigerant tube to the ground, and has a negative value when heat is transferred from ground to refrigerant tube.

The heat conduction equation in the axis-symmetric coordinate is shown as follows [29]:

$$
\rho C_{p} \frac{\partial T}{\partial t}=\frac{1}{r} \frac{\partial}{\partial r}\left(r k \frac{\partial T}{\partial r}\right)+\frac{\partial}{\partial z}\left(k \frac{\partial T}{\partial z}\right)
$$

Heat conduction equation for grout is with $r_{f e}<r<r_{b}$ :

$$
\left(\rho C_{p}\right)_{g} \frac{\partial T}{\partial t}=\frac{k_{g}}{r} \frac{\partial}{\partial r}\left(r \frac{\partial T_{g}}{\partial r}\right)+k_{g} \frac{\partial^{2} T_{g}}{\partial^{2} z}
$$

Here, $r_{f e}$ is radius of equivalent refrigerant tube; and $r_{b}$ is radius of grout, with $r_{b}<r<\infty$ :

$$
\frac{k_{s}}{r} \frac{\partial}{\partial r}\left(r \frac{\partial T_{s}}{\partial r}\right)+k_{s} \frac{\partial^{2} T_{s}}{\partial^{2} z}=\left(\rho C_{p}\right)_{s} \frac{\partial T_{s}}{\partial t}
$$

Boundary condition at the outermost boundary of domain is:

$$
\left.\frac{\partial T}{\partial r}\right|_{r=\frac{D_{s}}{2}}=0
$$

Boundary condition at the surface of refrigerant tube is:

$$
\left.T\right|_{r=\frac{D_{p e}}{2}}=T_{p i p e}
$$


with an initial condition $T_{\text {pipe }}=14.2^{\circ} \mathrm{C}$.

Ground surface boundary condition is:

$$
\left.T_{s}\right|_{z=0}=T_{\text {air }}
$$

Boundary condition for the bottom of the domain is:

$$
\left.T_{s}\right|_{z=150}=T_{s, \infty}
$$

Computational analysis is conducted for Equations (2)-(8) by discretization using finite volume method. Ground temperature is continuously varied according to depth, as time changes. However, after the depth reaches a certain value, the ground temperature variation maintains a constant annual temperature.

In this study, such a depth is defined as $150 \mathrm{~m}$, and the temperature at the depth is assumed to be $T_{s, \infty}=14.2{ }^{\circ} \mathrm{C}$ [24]. The ground heat exchanger is axis-symmetric, thus a two-dimensional analysis is conducted for computation analysis, while the boundary condition at the symmetric surface around the borehole is defined as zero gradient of temperature [29]. To analyze the ground heat conduction equation, the ground surface condition is needed along with the boundary condition. Thus, in this study, the regional annual climate data is used as the outdoor condition [30] and air is assumed to have the same properties as the outdoor condition [31].

\subsection{Cost of Electricity and Fuel}

A comparison of the late night electricity cost and the heat pump system operational cost is shown in Table 3. The cost of electricity generated from the fuel cell system is calculated using $46 \mathrm{won} / \mathrm{kWh}$ for hydrogen cost and $40 \%$ for fuel cell efficiency.

In this study, the energy cost is computed from the hydrogen cost and fuel cell efficiency, without taking into account the installation cost of the fuel cell. Also, the operational cost of the machines is excluded and only net energy cost is computed. The base price of late night electricity cost $t_{\text {base }}$ is computed from the following equation. In Equation (9), the $C O P_{\text {bath }}$ is the average of the hot water supply heat pump $C O P$, while $C O P_{\text {heating }}$ is the average of the heat pump heating $C O P$ :

$$
\begin{aligned}
\operatorname{cost}_{\text {base }}=( & \left(0.746 \times\left(4.73 \times\left(\frac{\text { bath heat pump capacity }}{\operatorname{COP}_{\text {bath }}}+\frac{\text { cooling and heating heat pump }}{\operatorname{COP}_{\text {heating }}}\right)\right.\right. \\
& + \text { fan power }+ \text { circulating pump power })+ \text { light load }) \times \operatorname{cost}_{b} \times 12
\end{aligned}
$$

where $\operatorname{cost}_{b}=$ basic cost.

\subsection{Heat Pump Capacity and Heat Storage Tank Calculation}

Heat pump capacity (HPC) is calculated from Equation (10) with the maximum daily load during a year obtained from the heating and cooling load program. The heat storage tank capacity is calculated from Equation (11):

$$
H P C(k J / h r)=P L(k J / d a y) \times \frac{S R}{O T(h r)}
$$




$$
R C\left(m^{3}\right)=\frac{H P C(k J / h r) \times N T(h r) \times S R-N L(k J)}{R T\left({ }^{\circ} C\right) \times R E \times 1,000\left(k J / m^{3}\right)}
$$

Here, $P L$ is maximum daily load; $S R$ is excess rate; $O T$ is heat source apparatus operating time; $N T$ is operating time during night; $N L$ is night load; $R T$ is temperature difference due to heat storage tank usage, and $R E$ is heat storage tank efficiency.

The temperature difference due to heat storage tank usage was assigned as $5{ }^{\circ} \mathrm{C}$, with a $10 \mathrm{~h}$ operating time during the night, a heat storage tank efficiency of $95 \%$, and an excess rate of $10 \%$. The amount of waste water was assigned as 1.8 times that of daily heated water, while heat storage tank capacity was the amount of the daily heated water, and the waste water storage tank capacity was 1.8 times that of the heat storage tank.

\section{Results and Discussion}

\subsection{Regional Data of Ground Temperature Variation}

In Korea, the heating load is larger than the cooling load, whereby more ground heat source is used during the winter than is stored heat during the summer; thus the ground temperature continuously decreases. Figure 5 shows the variation of ground mean temperature obtained from computational analysis. The difference of initial ground temperature according to the region is due to the fact that when the ground heat source is used, more heat is used than the amount stored in the ground heat source. Therefore the temperature difference in the ground is increased during use of the geothermal heat pump. Southern regions show a smaller decrease in ground temperature, while the northern regions show a larger variation in ground temperature. In southern regions, the heat load is small when heating with a ground heat source, making ground heat source recovery possible. However, in the northern regions, the amount of heat used is greater than the amount stored when heating with the ground heat source. Thus, after 1 year, the following ground temperature drop for each city is observed through computational analysis: in Busan, $1.5^{\circ} \mathrm{C}$; in Dajeon, $2.0^{\circ} \mathrm{C}$; and in Munmak $2.0^{\circ} \mathrm{C}$. Also, the increased use of the geothermal heat pump resulted in a greater decrease in temperature.

Figure 5. Variation of ground mean temperature.

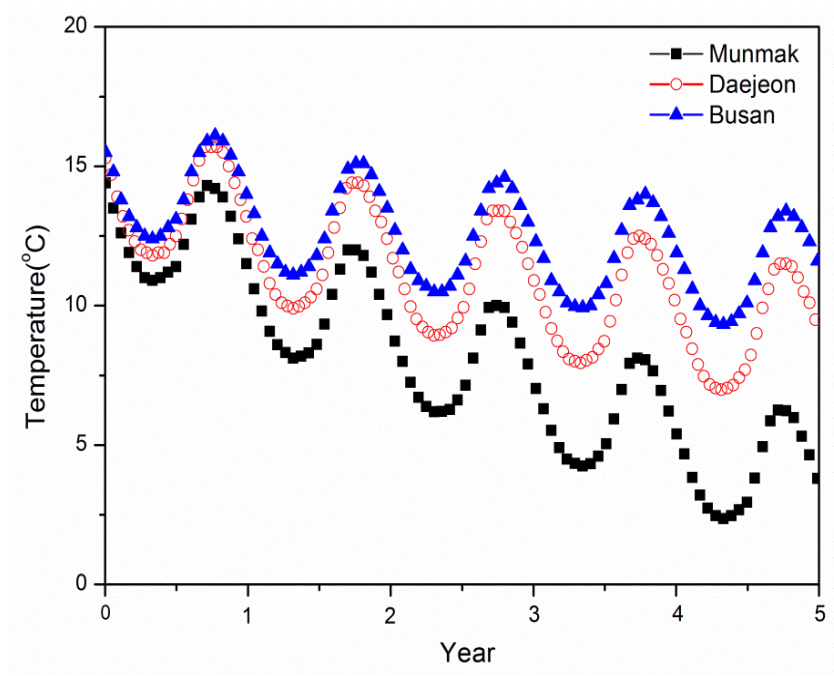


Thus, the most important issue in the geothermal heat pump system is how to compensate for the continual decrease of ground temperature. To resolve this problem, it is possible to control the system operation time and to store the heat source generated from summer cooling, as well as to use the heat source during winter heating. However, while this method can prevent ground temperature decrease, any long-term use of this system requires the use of multiple heat sources to deal with the continual decrease of ground temperature.

\subsection{Variation of Heat Pump System Performance According to Building Occupancy}

Figure 6 shows the ground temperature variation according to occupancy in different regions. Heat generated from the human body differs as occupancy varies, and affects the building heat and cooling loads as well as the ground mean temperature, thus affecting overall heat pump system performance. As can be observed from Table 3, a reduced heat pump system performance can result from a ground temperature drop when the annual average occupancy is $60 \%$. Thus, the adequate operation control is needed to maintain the ground mean temperature in different regions.

Figure 6. Effect of occupancy on the ground mean temperature. (a) Munmak; (b) Daejeon; (c) Busan.

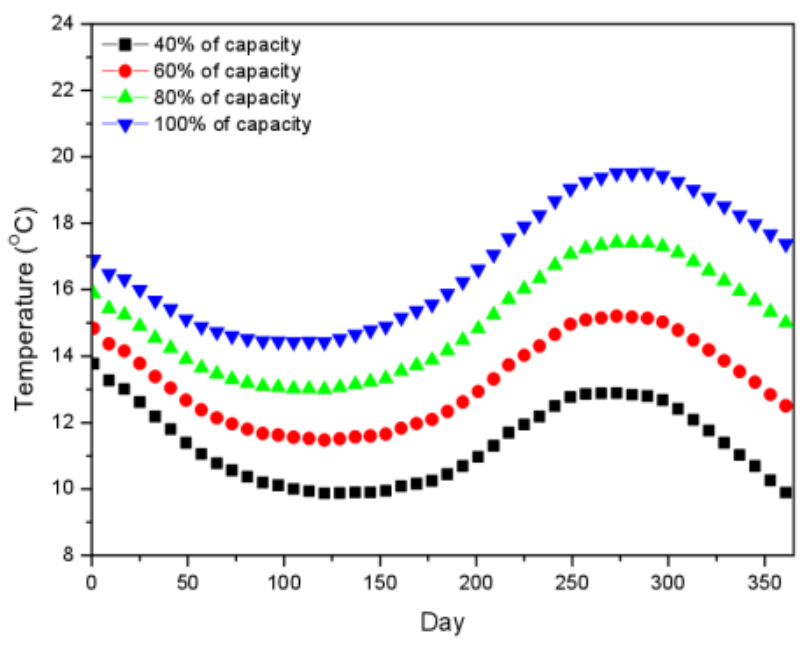

(a) Munmark

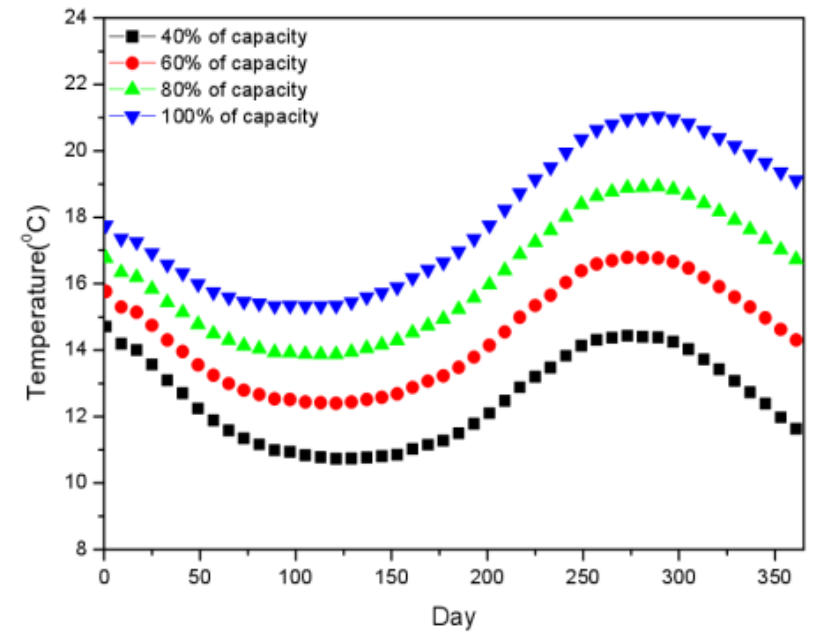

(b) Daejeon

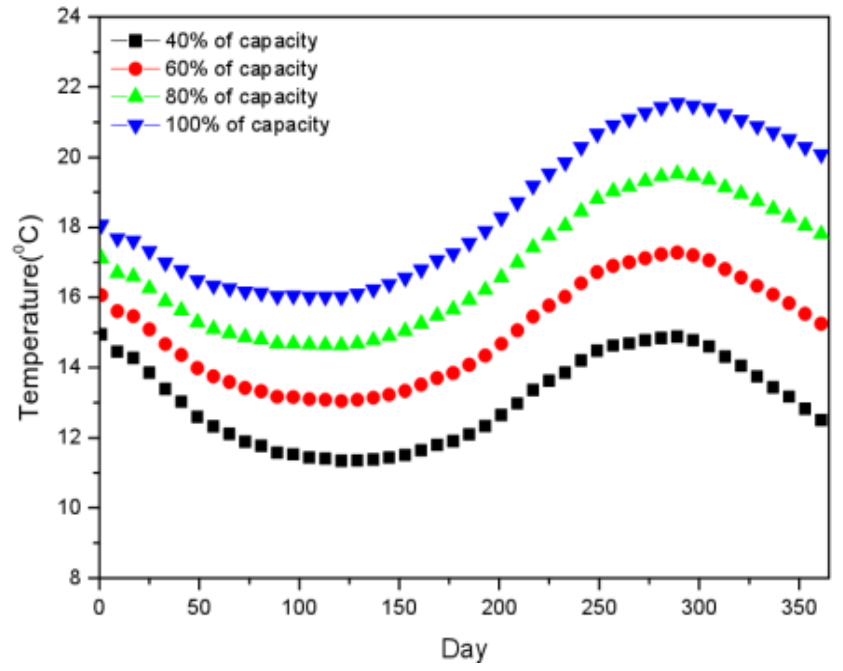

(c) Busan 
Table 3. Variation of mean ratio of number of people staying in the building to the maximum number of people staying in the building (total floor area $33,000 \mathrm{~m}^{2}$, Heat recovery, Night-electricity driven Ground source heat pump system).

\begin{tabular}{|c|c|c|c|c|c|c|c|c|c|c|}
\hline Location & $\begin{array}{c}\text { People } \\
\text { living in } \\
\text { building }\end{array}$ & $\begin{array}{c}\text { Hourly } \\
\text { maximum } \\
\text { cooling } \\
\text { load * }\end{array}$ & $\begin{array}{c}\text { Hourly } \\
\text { maximum } \\
\text { heating } \\
\text { load * }\end{array}$ & $\begin{array}{c}\text { Annual } \\
\text { maximum } \\
\text { cooling } \\
\text { load * }\end{array}$ & $\begin{array}{c}\text { Annual } \\
\text { maximum } \\
\text { heating } \\
\text { load * }\end{array}$ & $\begin{array}{c}\text { Heating and } \\
\text { cooling heat } \\
\text { pump } \\
\text { capacity * }\end{array}$ & $\begin{array}{c}\text { Bath heat } \\
\text { pump } \\
\text { capacity } \\
\text { (RT) }\end{array}$ & $\begin{array}{c}\text { Total } \\
\text { energy } \\
\text { cost ** }\end{array}$ & $\begin{array}{c}\text { COP } \\
\text { (heating) }\end{array}$ & $\begin{array}{c}\text { COP } \\
\text { (cooling) }\end{array}$ \\
\hline \multirow{4}{*}{ Munmak } & $40 \%$ & $-3,671,875$ & $5,969,645$ & $-3.92 \times 10^{9}$ & $11.30 \times 10^{9}$ & 1,731 & 267.6 & 11,363 & 3.60 & 6.57 \\
\hline & $60 \%$ & $-4,377,429$ & $5,993,169$ & $-5.29 \times 10^{9}$ & $10.75 \times 10^{9}$ & 1,681 & 267.6 & 16,552 & 3.75 & 6.12 \\
\hline & $80 \%$ & $-4,390,529$ & $5,999,053$ & $-6.85 \times 10^{9}$ & $10.46 \times 10^{9}$ & 1,668 & 267.6 & 16,572 & 3.84 & 5.68 \\
\hline & $100 \%$ & $-5,835,283$ & $6,040,654$ & $-8.53 \times 10^{9}$ & $9.58 \times 10^{9}$ & 1,620 & 267.6 & 16,611 & 4.40 & 4.52 \\
\hline \multirow{4}{*}{ Daejeon } & $40 \%$ & $-4,274,281$ & $5,125,525$ & $-5.42 \times 10^{9}$ & $9.28 \times 10^{9}$ & 1,583 & 267.6 & 12,386 & 3.67 & 6.40 \\
\hline & $60 \%$ & $-4,903,655$ & $5,126,583$ & $-6.97 \times 10^{9}$ & $8.40 \times 10^{9}$ & 1,544 & 267.6 & 16,562 & 3.94 & 5.85 \\
\hline & $80 \%$ & $-5,754,941$ & $5,128,469$ & $-8.69 \times 10^{9}$ & $7.94 \times 10^{9}$ & 1,492 & 267.6 & 16,578 & 4.23 & 4.78 \\
\hline & $100 \%$ & $-6,495,485$ & $5,130,355$ & $-10.5 \times 10^{9}$ & $7.39 \times 10^{9}$ & 1,460 & 267.6 & 16,721 & 4.53 & 3.98 \\
\hline \multirow{4}{*}{ Busan } & $40 \%$ & $-4,274,281$ & $5,125,525$ & $-5.80 \times 10^{9}$ & $9.28 \times 10^{9}$ & 1,498 & 267.6 & 11,363 & 3.68 & 6.40 \\
\hline & $60 \%$ & $-5,014,825$ & $5,126,104$ & $-7.48 \times 10^{9}$ & $8.15 \times 10^{9}$ & 1,434 & 267.6 & 11,731 & 3.94 & 4.93 \\
\hline & $80 \%$ & $-6,322,806$ & $4,574,010$ & $-9.28 \times 10^{9}$ & $6.26 \times 10^{9}$ & 1,631 & 267.6 & 16,351 & 4.01 & 4.88 \\
\hline & $100 \%$ & $-6,495,485$ & $5,130,355$ & $-10.5 \times 10^{9}$ & $6.22 \times 10^{9}$ & 1,788 & 267.6 & 17,070 & 4.54 & 3.98 \\
\hline
\end{tabular}

$*$ in $\mathrm{kJ} / \mathrm{h} ; *$ in ten thousand won.

\subsection{Heat Pump System Performance Variation for Various Heat Sources}

According to the results of this study, the air source heat pump using night time electricity and geothermal heat pump was modified so that the area was increased to $33,000 \mathrm{~m}^{2}$ during analysis of the standard model, and $60 \%$ occupancy was assumed. The same building model was used for locations Munmak, Dajeon and Busan. Computational analysis was conducted for each case. Calculated data includes hourly maximum heating and cooling load, annual heating and cooling load, heat pump capacity, hot water supply heat pump capacity, total energy cost, COP for each heat pump system, size of hot water supply, size of return heat storage tank, size of heat storage tank, pump power, and fan power. The heating and cooling heat pump capacity is calculated from the hourly maximum heating or cooling load that has a higher absolute value. Tables 4 and 5 show a comparison of air source and geothermal heat pump system performance using night time electricity and fuel cells. Observing the annual heating and cooling maximum load, Munmak resort has the highest heating load, followed by Dajeon and Busan. Busan has the highest cooling load, followed by Dajeon and the Munmak resort. In each case, the heat pump capacity is determined by either the maximum daily heating or cooling load, whichever is the larger. 
Table 4. Heat pump system simulation results for heating and cooling a resort building (total floor area 33,000 $\mathrm{m}^{2}$, Heat recovery, Night-electricity driven heat pump system).

\begin{tabular}{lcccccc}
\hline \multicolumn{1}{c}{ Location } & \multicolumn{2}{c}{ Munmak } & \multicolumn{2}{c}{ Daejeon } & \multicolumn{2}{c}{ Busan } \\
\hline Heat source & Air & Ground & Air & Ground & Air & Ground \\
\hline $\begin{array}{l}\text { Hourly maximum cooling } \\
\text { load (kJ/h) }\end{array}$ & $-4,390,529$ & $-4,390,529$ & $-4,903,655$ & $-4,903,655$ & $-6,322,806$ & $-6,322,806$ \\
\hline $\begin{array}{l}\text { Hourly maximum heating } \\
\text { load (kJ/h) }\end{array}$ & $5,999,053$ & $5,999,053$ & $5,126,583$ & $5,126,583$ & $4,574,010$ & $4,574,010$ \\
\hline $\begin{array}{l}\text { Annually maximum } \\
\text { cooling load (kJ/year) }\end{array}$ & $-4.66 \times 10^{9}$ & $-4.66 \times 10^{9}$ & $-6.17 \times 10^{9}$ & $-6.17 \times 10^{9}$ & $-6.55 \times 10^{9}$ & $-6.55 \times 10^{9}$ \\
\hline $\begin{array}{l}\text { Annually maximum } \\
\text { heating load (kJ/year) }\end{array}$ & $10.0 \times 10^{9}$ & $10.0 \times 10^{9}$ & $8.0 \times 10^{9}$ & $8.0 \times 10^{9}$ & $6.0 \times 10^{9}$ & $6.0 \times 10^{9}$ \\
\hline $\begin{array}{l}\text { Heating and cooling heat } \\
\text { pump capacity (kJ/h) }\end{array}$ & 1,668 & 1,668 & 1,418 & 1,418 & 1,631 & 1,631 \\
\hline $\begin{array}{l}\text { Bath heat pump capacity } \\
\text { (RT) }\end{array}$ & 267.6 & 267.6 & 267.6 & 267.6 & 267.6 & 267.6 \\
\hline $\begin{array}{l}\text { Total energy cost } \\
\text { (ten thousand won) }\end{array}$ & 18,371 & 16,572 & 18,306 & 16,562 & 17,702 & 16,351 \\
\hline COP (heating) & 3.16 & 3.84 & 3.27 & 3.94 & 3.42 & 4.01 \\
\hline COP (cooling) & 3.84 & 4.68 & 3.69 & 4.85 & 3.90 & 4.93 \\
\hline $\begin{array}{l}\text { COP (bath) } \\
\text { Thermal storage reservoir } \\
\text { for bath (t) }\end{array}$ & 4.21 & 4.18 & 4.21 & 4.18 & 4.21 & 4.18 \\
\hline $\begin{array}{l}\text { Waste heat recovery } \\
\text { storage reservoir (ton) }\end{array}$ & 511 & 511 & 511 & 511 & 511 & 511 \\
\hline $\begin{array}{l}\text { Thermal storage reservoir } \\
\text { for cooling and heating (t) }\end{array}$ & 2,209 & 2,209 & 1,879 & 1,879 & 2,161 & 2,161 \\
\hline $\begin{array}{l}\text { Pump power } \\
\text { (heating and cooling) }\end{array}$ & 46.1 & 46.1 & 39.4 & 39.4 & 48.8 & 48.8 \\
\hline $\begin{array}{l}\text { Pump power (bath) } \\
\text { Fan power (ventilation) }\end{array}$ & 6.2 & 6.2 & 6.2 & 6.2 & 6.2 & 6.2 \\
\hline
\end{tabular}

Table 5. Heat pump system simulation results for heating and cooling a resort building (total floor area $33,000 \mathrm{~m}^{2}$, Heat recovery, Fuel-cell driven heat pump system).

\begin{tabular}{lcccccc}
\hline \multicolumn{1}{c}{ Location } & \multicolumn{2}{c}{ Munmak } & \multicolumn{2}{c}{ Daejeon } & \multicolumn{2}{c}{ Busan } \\
\hline Heat source & Air & Ground & Air & Ground & Air & Ground \\
\hline $\begin{array}{l}\text { Hourly maximum cooling } \\
\text { load (kJ/h) }\end{array}$ & $-4,390,529$ & $-4,390,529$ & $-4,903,655$ & $-4,903,655$ & $-6,322,806$ & $-6,322,806$ \\
\hline $\begin{array}{l}\text { Hourly maximum heating } \\
\text { load (kJ/h) }\end{array}$ & $5,999,053$ & $5,999,053$ & $5,126,583$ & $5,126,583$ & $4,574,010$ & $4,574,010$ \\
\hline $\begin{array}{l}\text { Annually maximum } \\
\text { cooling load (kJ/year) }\end{array}$ & $-4.66 \times 10^{9}$ & $-4.66 \times 10^{9}$ & $-6.17 \times 10^{9}$ & $-6.17 \times 10^{9}$ & $-6.55 \times 10^{9}$ & $-6.55 \times 10^{9}$ \\
\hline
\end{tabular}


Table 5. Cont.

\begin{tabular}{lcccccc}
\hline \multicolumn{1}{c}{ Location } & \multicolumn{2}{c}{ Munmak } & \multicolumn{2}{c}{ Daejeon } & \multicolumn{2}{c}{ Busan } \\
\hline Heat source & Air & Ground & Air & Ground & Air & Ground \\
\hline $\begin{array}{l}\text { Annually maximum } \\
\text { heating load (kJ/year) }\end{array}$ & $10.0 \times 10^{9}$ & $10.0 \times 10^{9}$ & $8.0 \times 10^{9}$ & $8.0 \times 10^{9}$ & $6.0 \times 10^{9}$ & $6.0 \times 10^{9}$ \\
\hline $\begin{array}{l}\text { Heating and cooling heat } \\
\text { pump capacity (kJ/h) }\end{array}$ & 1,668 & 1,668 & 1,418 & 1,418 & 1,631 & 1,631 \\
\hline $\begin{array}{l}\text { Bath heat pump capacity } \\
\text { (RT) }\end{array}$ & 267.6 & 267.6 & 267.6 & 267.6 & 267.6 & 267.6 \\
\hline $\begin{array}{l}\text { Total energy cost } \\
\text { (ten thousand won) }\end{array}$ & 11,669 & 8,324 & 11,511 & 8,111 & 10,821 & 7,970 \\
\hline COP (heating) & 4.62 & 5.34 & 4.68 & 5.44 & 4.73 & 5.51 \\
\hline COP (cooling) & 3.84 & 4.68 & 3.69 & 4.85 & 3.90 & 4.93 \\
\hline COP (bath) & 4.21 & 4.18 & 4.21 & 4.18 & 4.21 & 4.18 \\
\hline $\begin{array}{l}\text { Thermal storage reservoir } \\
\text { for bath (t) }\end{array}$ & 511 & 511 & 511 & 511 & 511 & 511 \\
\hline $\begin{array}{l}\text { Waste heat recovery } \\
\text { storage reservoir (t) }\end{array}$ & 919 & 919 & 919 & 919 & 919 & 919 \\
\hline $\begin{array}{l}\text { Thermal storage reservoir } \\
\text { for cooling and heating (t) }\end{array}$ & 2,209 & 2,209 & 1,879 & 1,879 & 2,161 & 2,161 \\
\hline $\begin{array}{l}\text { Pump power } \\
\text { (heating and cooling) }\end{array}$ & 46.1 & 46.1 & 39.4 & 39.4 & 48.8 & 48.8 \\
\hline $\begin{array}{l}\text { Pump power (bath) } \\
\text { Fan power (ventilation) }\end{array}$ & 6.2 & 6.2 & 6.2 & 6.2 & 6.2 & 6.2 \\
\hline
\end{tabular}

Thus, Busan which has the largest maximum cooling load needs the largest heat pump capacity. Therefore, the base price for electricity rises. In determining the heat pump capacity, the optimal situation occurs when the amount of heating load and the amount of cooling load are similar. When either the heating load or cooling load is relatively large, the heat pump capacity and the size of the heat storage tank increase, thus increasing the cost of the initial installation and the cost of electricity. In Korea, the daily maximum heating load of the northern region is greater than that of the cooling load, which is the disadvantage in heat pump system application. Also, since the heating load is larger than the cooling load, the heat source used in winter is greater than the amount stored during the summer, thus resulting in a continual decrease of ground temperature. In southern regions, the ground temperature drop is less than in the Northern regions. In the ground source heat pump (GSHP), compensation of the continual increase or decrease of ground heat source is an important issue. Thus, in winter, heating the waste heat generated from the fuel cell operation can be used in system heating to yield a 1.5 COP increase in system performance compared to present ground heat source heat pump system. Electricity generated from the private power station can be supplied to the heat pump, saving energy costs. 


\subsection{Energy Cost}

The cost of energy in the heat pump heating and cooling system is calculated as the sum of the electricity cost for the heat pump power, the hot water heat pump power, and the fan power. The total cost varies slightly in a heat storage heat pump system, but the variance of total energy cost according to location is small in Munmak, Dajeon, and Busan. In Busan, while the cooling energy cost is the largest, it has a small heating load energy cost. On the contrary, Munmak has a large heating load energy cost, but has a small cooling load energy cost. Thus, the sum of heating and cooling load energy cost was similar for Busan and Munmak. Table 6 shows the cost of electricity, gas, and the sum when absorption cooler-heat system is used instead of the heat pump system. Cases are classified by whether the public bath is installed in the resort and whether the waste heat is recovered. Cases are classified by whether the public bath is installed and whether the waste heat is recovered. In the cases when the public bath is installed and the waste heat is not recovered, total energy cost showed about a $0 \%-5 \%$ increase.

Table 6. Energy cost of gas absorption cooler-heater system for a resort building (total floor area $=33,000 \mathrm{~m}^{2}$ ).

\begin{tabular}{|c|c|c|c|c|c|c|c|}
\hline \multirow{2}{*}{ Location } & \multirow{2}{*}{$\begin{array}{c}\text { Energy cost } \\
\text { Bath existence }\end{array}$} & \multicolumn{2}{|c|}{ Munmak } & \multicolumn{2}{|c|}{ Daejeon } & \multicolumn{2}{|c|}{ Busan } \\
\hline & & Non-exist & Exist & Non-exist & Exist & Non-exist & Exist \\
\hline \multirow{3}{*}{$\begin{array}{l}\text { Heat } \\
\text { recover }\end{array}$} & $\begin{array}{c}\text { Absorption } \\
\text { cooler-heater gas cost } \\
\text { (ten thousand won) }\end{array}$ & 38,988 & 38,988 & 37,464 & 37,464 & 34,594 & 34,594 \\
\hline & $\begin{array}{c}\text { Absorption } \\
\text { cooler-heater electric cost } \\
\text { (ten thousand won) }\end{array}$ & 24,966 & 24,973 & 24,003 & 23,997 & 22,166 & 22,159 \\
\hline & $\begin{array}{c}\text { Absorption } \\
\text { cooler-heater total cost } \\
\text { (ten thousand won) }\end{array}$ & 63,954 & 63,961 & 61,467 & 61,416 & 56,760 & 56,753 \\
\hline \multirow{3}{*}{$\begin{array}{l}\text { Non heat } \\
\text { recovery }\end{array}$} & $\begin{array}{c}\text { Absorption } \\
\text { cooler-heater gas cost } \\
\text { (ten thousand won) }\end{array}$ & 53,300 & 53,300 & 51,766 & 51,776 & 48,906 & 48,906 \\
\hline & $\begin{array}{c}\text { Absorption } \\
\text { cooler-heater electric cost } \\
\text { (ten thousand won) }\end{array}$ & 24,189 & 23,280 & 23,213 & 22,346 & 21,372 & 20,537 \\
\hline & $\begin{array}{c}\text { Absorption } \\
\text { cooler-heater total cost } \\
\text { (ten thousand won) }\end{array}$ & 77,489 & 76,580 & 74,989 & 74,122 & 70,281 & 69,443 \\
\hline
\end{tabular}

Table 7 shows a comparison of the total energy cost in a resort building when various heat sources are used. The large energy cost for gas absorption cooling-heating is due to an expensive fuel cost and general electricity cost, thus showing the largest energy cost. Energy cost difference according to location was slight in the air source and ground source heat pump system using night time electricity. Thus fuel cell driven heat pump system with a high system performance coefficient and low unit price showed the lowest energy cost. 
Table 7. Comparison of operation costs.

\begin{tabular}{lccc}
\hline \multicolumn{1}{c}{ Heat pump heating and cooling system } & Munmak & Daejeon & Busan \\
\hline Gas absorption cooler-heater(ten thousand won) & 76,580 & 74,122 & 69,443 \\
\hline $\begin{array}{l}\text { Gas absorption cooler-heater + waste heat recovery } \\
\text { (ten thousand won) }\end{array}$ & 63,961 & 61,461 & 56,753 \\
\hline $\begin{array}{l}\text { Night-electricity driven air source heat pump water } \\
\text { storage (ten thousand won) }\end{array}$ & 18,371 & 18,306 & 17,702 \\
\hline $\begin{array}{l}\text { Night-electricity driven ground source heat pump } \\
\text { water storage (ten thousand won) }\end{array}$ & 16,572 & 16,562 & 16,351 \\
\hline $\begin{array}{l}\text { Fuel cell driven air source heat pump water storage } \\
\text { (ten thousand won) }\end{array}$ & 11,669 & 11,511 & 10,821 \\
\hline $\begin{array}{l}\text { Fuel cell driven ground source heat pump water } \\
\text { storage (ten thousand won) }\end{array}$ & 8,324 & 8,111 & 7,970 \\
\hline
\end{tabular}

\section{Conclusions}

In this study a ground source heat pump heating and cooling system driven by a fuel cell was computationally analyzed, in which heat pump system performance and economic feasibility were considered. Ground temperature ground the pipe is affected both by the variation of air temperature in the pipe brine temperature. The results are as follows:

(1) While the fuel cell driven heat pump system incurs a high initial installation cost, the cost is expected to decrease as fuel cell technology is developed. Also, night time electricity is predicted to increase, thus the fuel cell driven heat pump system will be competent to night time electricity driven heat pump system in future. Also the fuel cell system can be operated without limit in time and thus the size of heat storage tank can be decreased, which is an advantage over night time electricity driven heat pump system.

(2) In Korea, where the heat load is larger than the cooling load, a continuous operation of ground heat source heat pump system is bound to lead to a continual drop in ground temperature. The system is also affected by outer conditions such as occupancy. Therefore, the fuel cell driven system can increase COP by using waste heat generated from the system and minimize ground temperature drop.

(3) A fuel cell driven ground heat source heat pump system increased the COP heating by about 1.5 through waste heat recovery.

\section{Acknowledgments}

This work was supported by the Human Resources Development program (No. 20124010203250) of the Korea Institute of Energy Technology Evaluation and Planning (KETEP) grant funded by the Korea Government Ministry of Knowledge Economy and by a Korea University Grant (T1101411).

\section{References}

1. Kim, O.J.; Hong, Y.J.; Nam, L.W.; Kang, W.I.; Kong, Y.S. Cycle simulation of an air source heat pump using liquid injection. Korea J. Air Cond. Ref. Eng. 2000, 12, 244-250. 
2. Kavanaugh, S.P.; Raffery, K. Ground-Source Heat Pumps: Design of Geothermal Systems for Commercial and Institutional Buildings; American Society of Heating, Refrigerating and Air-Conditioning Engineers (ASHRAE): Atlanta, New York, NY, USA, 1997.

3. Healy, P.F.; Ugursal, V.I. Performance and economic feasibility of ground source heat pumps in cold climate. Int. J. Energy Res. 1997, 21, 857-870.

4. Phetteplace, G.; Sullivan, W. Performance of a hybrid ground-coupled heat pump system. Am. Soc. Heat. Ref. Air Cond. Eng. Tans. 1997, 104, 763-770.

5. Bose, J.E.; Parker, J.D.; McQuiston, F.C. Design/Data Manual for Closed-Loop Ground-Coupled Heat Pump Systems; ASHRAE: Atlanta, New York, NY, USA, 1985.

6. Stoecker, W.F. Procedures for Simulating the Performance of Components and Systems for Energy Calculations; ASHRAE: Atlanta, New York, NY, USA, 1975.

7. Mei, V.C.; Baxter, V.D. Experimental study of direct-expansion ground coil heat exchangers. Am. Soc. Heat. Ref. Air Cond. Eng. Tans. 1990, 96, 634-642.

8. Bose, J.E. Closed-Loop Ground-Coupled Heat Pump Design Manual; Engineering Technology Extension; Oklahoma State University: Stillwater, OK, USA, 1984.

9. Bose, J.E. Closed-Loop/Ground-Source Heat Pump Systems Installation Guide; Engineering Technology Extension; Oklahoma State University: Stillwater, OK, USA, 1988.

10. Kavanaugh, S.P. Development of design tools for ground-source heat pump piping. Am. Soc. Heat. Ref. Air Cond. Eng. Tans. 1998, 104, 932-937.

11. Cane, D.; Morrison, A.; Christopher, J. Operating Experiences with Commercial Ground-Source Heat Pump Systems; ASHRAE: Atlanta, New York, NY, USA, 1998.

12. Lund, J.W. Direct-use of geothermal energy in the USA. Appl. Energy 2003, 74, 33-42.

13. Lund, J.W.; Freeston, D.H. World-wide direct uses of geothermal energy 2000. Geothermics 2001, $30,29-68$.

14. Zeng, H.; Diao, N.; Fang, Z. Heat transfer analysis of boreholes in vertical ground heat exchangers. Int. J. Heat Mass Trans. 2003, 46, 4467-4481.

15. Hepbasli, A.; Akdemir, O.; Hancioglu, E. Experimental Study of A Closed Loop Vertical Ground Source Heat Pump Systems; ASHRAE: Atlanta, New York, NY, USA, 2003.

16. Bi, Y.; Chen, L.; Wu, C. Ground heat exchanger temperature distribution analysis and experimental verification. Appl. Therm. Eng. 2002, 22, 183-189.

17. İnall, M.; Esen, H. Experimental thermal performance evaluation of a horizontal ground-source heat pump system. Appl. Therm. Eng. 2004, 24, 2219-2232.

18. Esen, H.; İnall1, M.; Esen, M. Technoeconomic appraisal of a ground source heat pump system for a heating season in eastern Turkey. Energy Convers. Manag. 2004, 47, 1281-1297.

19. Houchins, C.; Kleen, G.J.; Spendelow, J.S.; Kopasz, J.; Peterson, D.; Garland, N.L.; Ho, D.L.; Marcinkoski, J.; Martin, K.E.; Tyler, R.; Papageorgopoulos, D.C. U.S. DOE progress towards developing low-cost, high performance, durable polymer electrolyte membranes for fuel cell applications. Membranes 2012, 2, 855-878.

20. Lee, C.S.; Choi, Y.D. Analysis of energy consumption of office building by thermal resistance-capacitance method. Korea J. Air Cond. Ref. Eng. 1997, 9, 1-13.

21. Lee, C.S. Development of a Building Energy Analysis Computer Program Using the Resistance-Capacity Method. Master Thesis, Korea University, Seoul, Korea, 2003. 
22. Lee, J.H.; Choi, Y.D.; Cho, S.H. A Comparison on Simulation Results of Load Analysis Program. In Proceedings of Society of Air-Conditioning and Refrigerating Engineers of Korea (SAREK 1999), Seoul, Korea, 30 November 1999; pp. 51-64.

23. Choi, Y.D.; Yoon, J.H.; Hong, J.K.; Lee, N.H.; Kang, D.H. Simulation of the thermal performance on an ondol house with hot water heating in consideration of radiation heat transfer. J. Air Cond. Ref. 1994, 8, 3-16.

24. Jeong, D.H.; Byun, J.K.; Choi, Y.D.; Cho, S.H. Study on the performance fuel cell driven compound source heat pump system to a large community building. New Renew. Eng. 2008, 4, 23-35.

25. ASHRAE Handbook 1993 Fundamentals; ASHRAE: Atlanta, New York, NY, USA, 1993; pp. 27.9-27.11.

26. ASHRAE Handbook 1993 Fundamentals; ASHRAE: Atlanta, New York, NY, USA, 1993; pp. 27.27-27.28.

27. Choi, Y.D.; Han, S.H.; Cho, S.H.; Kim, D.S.; Um, C.J. Study on the simulation of heat pump heating and cooling systems to hospital building. Korea Soc. Mech. Eng. 2008, 32, 275-282.

28. Shim, Y.B.; Park, K.J.; Jung, D.S.; Kim, J.S. Condensation heat transfer coefficients of R245fa on a plain tube. Int. J. Air Cond. Ref. 2007, 19, 555-562.

29. Patankar, S.V. Numerical Heat Transfer and Fluid Flow; McGraw-Hill: New York, NY, USA, 1980.

30. Choi, Y.D.; An, J.S.; Kim, W.K.; Park, H.S.; Jang, M.S. Analysis on the Thermal Performances of Cool Tube Systems for One Year. In Proceedings of The Korean Society of Mechanical Engineering, Pusan National University, Pusan, Korea, 17-19 April 1996; pp. 725-731.

31. Tromble, A.; Serres, L. Air earth exchanger study in real site experimentation and simulation. Energy Build. 1994, 4, 23-35.

(C) 2013 by the authors; licensee MDPI, Basel, Switzerland. This article is an open access article distributed under the terms and conditions of the Creative Commons Attribution license (http://creativecommons.org/licenses/by/3.0/). 